\title{
19. The Joke in History
}

Delivered in Coombs Seminar Room E, ANU, 26 April 2006.

It was 1965. The travelling salesman got off the train in Wycheproof, and walked into the draper's shop. Now, for those of you that don't know the area, that is not a long walk. The Bendigo-Sea Lake train runs down the middle of Broadway, the main street in Wycheproof. The salesman slung his case of samples on the counter. He was smartly dressed, but not too smartly. He wants to show he is from the city, he knows good clothes, he is not a failure, but he is not a cityslicker. He says, 'Hullo, Mr Cuthbert. Still busy. Still running the best business in town?' He is friendly but not too matey. It's 'Mr Cuthbert'. He flatters, because that is expected, but not excessively. He pauses, smiles and he says, 'Did you hear about the newly married couple? They couldn't tell the difference between Vaseline and putty. You guessed it, Mr Cuthbert. A tragedy. First windy day, all their windows fell out'. Again he has to get it right. He brings the latest joke and it has to be on the edge of outrageous. It will be overheard by a woman sitting on a high stool turning over the pages of Butterick's thick pattern catalogue. It has to be at the level where Mrs Williamson will later say, 'You'll never guess what I heard in Cuthbert's. I could never repeat it'. But, with just the right amount of encouragement, of course she does.

I told that story because I want you to have three points in mind: jokes have a context - they are told in a particular place to a particular audience; jokes have a function - and that is obvious in the case of the salesman; and there can be a fine line on whether the teller has got the joke right - because jokes often deal with sex, race, religion, nationality, politics, abnormalities and grossness. There was this Anglican vicar, a Catholic priest and a Jewish rabbi who were called upon to bless the mayor's new car ... but you all know the joke.

A senior travelling salesman took a young colleague to his first annual salesmen's dinner. It was a fine occasion, and after the entrée and the formal toasts, various guests finished a mouthful of rack of lamb, stood up, gained attention, and called out a number: ' 75 ' or ' 17 ' or ' 38 '. Each number was followed by thighslapping, uproarious laughter. The young salesman asked his older mentor what was going on.

'Oh', said the older salesman. 'I'm sorry. I should have explained. You've got your travelling salesman's joke book? Well all of us know the jokes in there so well, we save time by just calling out the joke's number'.

'Great idea', said the young salesman, 'Can I have a go?'

'Of course. Of course'. 
So the young salesman pulled out his joke book, flicked through, put it back in his pocket, stood up a bit self-consciously, and said, ' 26 '. There was no laughter, not even a snicker. Deflated, he sat down.

'What went wrong?' he asked.

'Well', said the older salesman, 'It was the timing'.

There is a craft to the writing and the telling of jokes. Same jokes and different tellers get different responses. Context, function, edge and craft.

When Tim Bowden and I were collecting material on the experiences of Australian prisoners of war of the Japanese, many of the ex-prisoners told us the same joke. Soon after they surrendered in Singapore on 15 February 1942, many Australian prisoners were sent from Changi into Singapore City on work parties. There they cleaned up the debris of battle, worked on the wharves and - just to rub it in - built a memorial shrine to the Japanese dead. Soon the men were short of food, in fact short of everything, and they began 'scrounging'. That is, they began thieving. They felt justified in doing this because they were taking from the enemy; they thought that by international law they were being shortchanged; and they soon learnt that either they stole or they died. Men took pride in the art of scrounging. But the penalties were often arbitrary, immediate and horrific. One day a Japanese guard walked on to a work site, called the men together, took a digger's slouch hat and casually dropped it over a tin of condensed milk. He then said 'You Australians think I know fuck nothing. I tell you I know fuck all'. Then, with exaggerated casualness he walked over to where he had left the slouch hat and went to pick up the hat and the tin. But his hand closed on the limp hat. There was no tin. Some digger had pinched it while he was talking.

If the incident happened at all, then at most forty or fifty prisoners saw it, and later Tim and I were to say that we had spoken to eighty of them. It was a story that spread rapidly and widely among the prisoners, and Australian prisoners wanted to claim it as their own. The story raced nearly all the ex-prisoners home. Able Seaman Arthur Bancroft, he was called 'Blood' Bancroft because of his red hair, was on the cruiser Perth when it was sunk in Sunda Strait. Blood was one of just half the crew that survived battle and drowning. He was imprisoned in Java, shipped to Singapore in October 1942, and became part of 'A' Force that went to Burma to work on the Burma-Thailand Railway. Having recovered a little of his strength, Blood was selected to go to Japan to work in shipyards and mines. The Japanese brought him down the Mekong to Saigon, but by this time Japanese shipping was being disrupted by Allied bombing and American submarines. Blood was sent back to Phnom Penh by river ferry and then by train across Southeast Asia to Singapore. In September 1944 he went 
on board the Japanese transport Rokyu Maru, and was soon at sea in a convoy on its way to Japan. American submarines attacked in the South China Sea sinking several ships. The Rokyu Maru with about 1250 prisoners crammed on board was one. After a few days the American submarines came back through the wreckage they had wrought. They picked up Blood after he had been six days in the water. He was one of eighty Australians taken to Saipan and from there to Australia. In collaboration with R.G. Roberts, Arthur Bancroft wrote his account of being a prisoner of war, The Mikado's Guests. The austere war-time edition of Blood's account came out before the end of the war, and obviously before there was any pattern of how to characterise the behaviour of captors or captives. Early in his memoir, Bancroft takes delight in the Australians' skill as thieves: he says, 'Ali Baba and his Forty Thieves were mere amateurs'. He returns to the theme near the end of the book and tells the story of the hat and the disappearing can of milk.

Blood's was the first of a long line of reminiscences. They still come. Rowley Richard's A Doctor's War was published in 2005 when Rowley was 88. So that's sixty years of reminiscences. And the tin disappears often. Rowley skipped that story, but the bold claim 'I know fuck-all' was used in Alan Hopgood's play 'Weary' which had its premiere in Canberra in February 2005. I was probably the first to put the 'fuck-all' line into print (that was in 1985) so I was pleased to hear it get a good laugh in the Canberra Theatre Centre.

We can speculate about why the Australians liked the hat and disappearing tin joke and wanted to appropriate it. It's one of the weapons of the oppressed and the threatened with no chance to speak openly to have jokes in which they triumph and the oppressors are shown to be stupid. The hat joke is also one in which there is no horror and the Japanese are not shown to be brutal. The teller often begins, 'This Jap wasn't a bad bloke but he knew just enough English to get himself into trouble ...' In Blood Bancroft's account, at the end of the day an Australian pulled the tin from his pocket and threw it to the guard with a cheerful, 'Here's your can of milk, Nip'. The surprised guard recovered, laughed and threw it back saying, 'Australia Number One'. The hat joke is one that presents the Australians as winning and taking the initiative when they had suffered defeat and were humiliated and smarting at their own impotence. It presents them as they want others to see them - displaying a casual larrikin indifference to authority and being winners; and it's a story that (with some moderation of the 'fuck-all' line) can be told anywhere. There is no starvation, no brutality, and no deaths. The Australians are the worthy sons of Ned Kelly and the Anzacs and the Japanese are generous in their acknowledgment. 
The hat joke may well have been first told in Australia by convicts at Sydney Cove. If people know of any record of this joke circulating among light-fingered slaves working on Hadrian's Wall or the Hanging Gardens of Babylon they can let me know.

But the point I want to make about this joke is that it has a history. Jokes are in our history and they themselves have a history, a provenance. So context, function, edge, craft and history.

Three different things provoked me into thinking about jokes. The first was reading Michael Young's first volume of his biography of Bronislaw Malinowski (Malinowski: Odyssey of an Anthropologist 1884-1920, Yale University Press, New Haven, 2004). This is a book based on wide and detailed research, assessing a leading social scientist of the twentieth century, presenting it to a world readership and requiring sustained scholarly writing. The need to write well is all the greater because Malinowski was himself a fine writer who engaged a wide range of readers and exposed them to a new discipline and the frontiers of scholarship about human behaviour. Young succeeds. His prose is always sharp and clear, and he has a consciousness of structure that goes beyond ensuring that there is an orderly sequence of narrative and analysis. Here is Young's summary: Malinowski 'could be moody, irritable, hypersensitive, self-absorbed, vain, petulant, foul-mouthed, sentimental and melancholic. But he could also be gregarious, emotionally generous, deeply courteous and scintillatingly eloquent. He was a demonically hard worker whose zeal galvanized those around him' (p. $\mathrm{xxv}$ ). While reading this book, I found that I was often amused by the incidents described, the author's touches of irony and the occasional joke. After having introduced Borenius, a Finn who was a friend of Malinowski's in London, Michael Young has the single line: 'Malinowski liked to pun: "I supply the polish and Borenius the finish"' (p. 176). Other historians would have put that line in a footnote; or left it out altogether, but told it often in conversation.

The second stimulus to thinking about jokes in history was reading Alan Powell's The Third Force, a history of Angau, the Australian New Guinea Administrative Unit, the army unit that took over the administration of New Guinea during World War II. This is a book dense with detail. But just occasionally, there is an arresting anecdote. The American 1st Marine Division landed on Cape Gloucester in west New Britain on Boxing Day 1943. The 1st Marines had fought on Guadalcanal, rested and retrained in Australia. They were experienced and tough. They were supported by aircraft and a massive naval bombardment. On that first day, they put ashore over 12,000 troops and 7,600 tons of equipment. A few Australians in Angau went ashore with the Americans. Two of them were Keith McCarthy and Mark Pitt, both had served in the prewar administration in New Guinea and they knew each other well. Alan Powell quotes Keith McCarthy: 
'How goes it?' I shouted in Mark's ear, amid the fantastic din. 'No good', growled Pitt. 'The natives are completely out of control. They deserted their villages and won't obey my orders to come in'. 'Good God, man! You wouldn't expect them to do anything else with a bloody war all around them, would you?' 'It's no good', said Mark. 'They're ruined. The native sense of discipline is gone'. (Powell, p. 248)

In his introduction to the incident, Powell says that it could serve as a 'requiem for the pre-war social relations'. And at the end of the incident he makes no further comment. It is nicely used. It arises easily from what has gone before, and it is both evidence and illustration of the point that Powell wants to make about the dramatic and terrible disruption of war and the nostalgia of some of the whites for the prewar order. And it's funny.

The third thing that provoked me to think about jokes and how they are told and used was last year's reunion of the Boort football club's fiftieth anniversary of its 1955 premiership. I got an invitation as I had been a teenage member of the second eighteen. We did not win anything - except a few fights. We did a lap of honour when our captain won the toss. The reunion spread over several events. One was a lunch for about sixty people on the Saturday before that afternoon's game. After a formal welcome and the guest speaker, people were invited to the microphone to say whatever they thought appropriate. Many spoke. And many of them chose to recount incidents. The stories came in a style familiar to me, but I had forgotten how well they could be told. Strawb wandered up to the microphone. His real name is Aubrey, but that rhymes with strawberry which was reduced to 'Strawb'. Strawb began, 'We were playing the "Burn"'. That is Wedderburn. 'Wind and showers were blowing across the ground, and like a mob of cattle looking for shelter, many of the "Burn" had mobbed up on the half-forward flank. Redda and the ball were somewhere in the middle of the pack. Now as you know', Strawb said, 'Redda had more courage than sense'. Everyone turned and had a look at Redda. Stawb continued: 'So finding himself completely surrounded by red and black jerseys Redda knew what he had to do: retaliate first. So he clouted the closest bloke. All hell broke loose. In between swinging desperate punches Redda called to me. I was the only team mate within seventy yards: "Come on Strawb. Back-to-back and we'll have these bastards"”.

Strawb paused here and that gives me a chance to explain that before he began to talk Strawb had to lower the microphone. He is about $5 \mathrm{ft} 7^{\prime \prime}$, standing on a box.

Strawb continued, 'So I said to Redda: "I see your predicament, Redda, and I appreciate the way you have selected me. But I wonder, Redda, if you could see your way clear to call upon one of the others"'. 
With that Strawb left the microphone and returned to his seat and another of the old team mates wandered up.

It was one of many well-expressed and carefully crafted anecdotes. No doubt it had been through several edits during its many retellings. It was now sharp, concise and effectively underplayed. I realised that there were not many of my colleagues who, equipped with a better vocabulary and with the advantage of having dissected many a literary text, corrected a thousand student essays and worked long and hard on their own prose, could have told their stories as well as the country footballers at their fiftieth reunion. One difference is that those country footballers live within communities where the ability to hone and tell an anecdote is appreciated. Not all attempt to do it, but those who do it publicly had better do it well. Criticism of the failed anecdote may be short on detail, but it cannot be misunderstood. It may come in words such as, 'Bert, if I hear you mangle that yarn again, I'll spilt your head with a tyre lever and personally remove the defective bit of brain where good yarns go in and crap comes out'. That's shearing shed lunch-time lit crit.

It was at about this time at the reunion that Wychitella Byrnes said that we needed to problematise the definitional relationships between modes of mirth evocation. Wyche used to be the Jacques Lacan of the Buckrabanyule watershed; but after the drought broke in the spring he shifted to selling off Dorset-Merino first cross fat lambs. Wyche had a point. The price of lambs went up. But not forgetting the nuanced discourse space he had once adumbrated, Wyche led us in a chorus of that hymn: 'Oh what a friend we have in exegeses'.

Had any of that ever crossed Wyche's mind, he would have been right about the need for some sorting out of what we mean by 'joke'. I have, as should have been obvious, been laying out examples of a formal joke, wit with words, anecdotes, and the send-up which itself may range from gentle irony to sarcasm and to the absurd. I will try and illustrate some more about the differences, and say something about the utility of each for writers.

William Manchester the American novelist, biographer and historian wrote one of the most quoted, but not most reliable, biographies of General Douglas MacArthur: American Caesar, 1978. Manchester himself had fought as a marine from Guadalcanal to Okinawa, and the marine corps was navy, and MacArthur was army. Manchester and the marines were fighting close to MacArthur's army and competing with it for supplies and on strategy, and post-battle they competed for recognition and glory. Manchester's story of his war is told in Goodbye, Darkness: A Memoir of the Pacific War, 1980. The easy-going friendly Admiral Chester Nimitz, commander-in-chief of the Pacific fleet, was the man who was the direct competitor to the egocentric MacArthur. They met before 
the invasion of Hollandia and Aitape in 1944. I think they met in Australia, and not New Guinea. Here is Manchester writing of the encounter between the competing commanders:

Addressing their two staffs, Nimitz said of himself and MacArthur that 'the situation reminds me of the story of the two frantically worried men who were pacing the corridor of their hotel. One finally turned to the other, "What are you worried about?" The answer was: "I am a doctor and I have a patient in my room with a wooden leg and I have the leg apart and can't get it back together again". The other responded: "Great guns, I wish that was all I had to worry about. I have a great-looking gal in a room with both legs apart, and I can't remember the room number"'.

That's a joke, but Manchester can get away with it because Nimitz told it, and it says something about the contest between MacArthur and Nimitz, and the style of Nimitz. Generally, I am not keen on the sorts of jokes that get into the commercial travellers' handbook of numbered jokes for all occasions.

For historians the anecdote often works better. When we were collecting material for Taim Bilong Masta we heard many superb anecdotes, some of which we could not use. This is another story from Keith McCarthy, the author of the incident on Cape Gloucester quoted by Alan Powell.

In the late 1930s Keith was Assistant District Officer at Talasea on New Britain. On one of his inspections of plantations on the coast east of Talasea, he arrived on the same day as the Burns Philp steamer. The planters had had a tough time during the depression, and the price of copra remained low at the end of the decade. The planter, I'll call him Axel because he was a Scandinavian, was desperate to get his copra loaded. He knew that the Burns Philp captain would give him little sympathy. If weather or schedule demanded that he pull away from the plantation jetty, he would, and there was not likely to be another boat for six weeks or so. Keith had no chance of inspecting labourers or records and he settled to watch the activity. The copra was being carted to the jetty by bullock cart. The bullock was moving with the slow, steady tread of the good working bullock, and the somnolent New Guinean driver sat on the shaft. Axel rushed up and in furious pidgin demanded that the driver give the bullock a hurry-up. The New Guinean gave the bullock a casual flick with his long cane, and the bullock's tread did not change. Axel abused the New Guinean, hauled him off his seat, snatched the cane, and belted the bullock. Disturbed by all this the bullock stopped and turned its head to have a look at what was going on. Axel, with increased fury, grabbed the head of the bullock to make it face in the direction of the jetty, and gave the bullock a round arm clout. Now a 
bullock's skull is heavy bone. Axel's fist rebounded, and from this point on you must imagine Axel with one bruised hand and a near-paralysed arm tucked into his side.

Axel seized on a plan to both punish the bullock and force it into plenty of hurry up. He grabbed some dried palm fronds, stacked them under the bullock's belly and with great difficulty with his one good hand and one half-paralysed arm, lit a match. As soon as the bullock felt the heat it moved forward, and as soon as the heat stopped so did the bullock. But the fire was now under the dray. By this time an audience of plantation labourers had gathered. All looked solemn and concerned. Not a flicker of a smile crossed one face. Axel screamed abuse and a few labourers went off, not too quickly, to get buckets of water, and others gathered around the smoking dray, but to the fury of Axel they were doing more looking than fire-fighting. Suddenly dray and copra burst into flame. With heat and a crackling fire behind it the bullock took off. It dashed down the slope, dragging its flaming chariot, clattered on to the end of the jetty, failed to run a straight line, plunged over the side, and stood with waves breaking along its heaving sides and the smoking copra bags drifting away from the dray.

The war came, passed and Keith McCarthy returned to New Britain. Keith was easily recognised. He was big and he had sandy red hair. He came back to Axel's plantation. But Axel was not there; the plantation had been regenerated by a new owner. He saw an older New Guinean looking at him, and after a while the New Guinean said, 'Macarti?' - as Keith was always known. 'Bipo taim bilong pait long ol man bilong Japan'. 'You were here before the war'.

As the two began to talk, other New Guineans gathered around. The man who first spoke identified himself as the driver of the bullock dray for Masta Axel. All the New Guineans knew the story of steamer day and the great hariap. They began a familiar narrative with familiar actions. 'Wanpela bulamakau tanim pinis het bilong en, isi isi'. 'The bullock turned his head, slowly slowly'. And several of them turned their heads slowly. 'Masta Axel paitim het bilong bulamakau'. They flung the punch, suffered jarring pain in the hand and arm, and tucked the injured wing against their sides. They rolled with laughter as they said how the bullock moved forward and the fire was then under the dray. As some did Masta Axel's shouted abuse others rolled their eyes, said sorry many times, clicked their tongues and generally played the role of those who want to look like they are worried and trying to help, but are unable to understand and have no initiative. They described the last mad dash of the bullock, and all pretended to look over the side of jetty before falling over each other in an explosion of laughter.

Steamer day at Axel's plantation is a great anecdote. It tells us much about the desperation of the planters who were in debt and dependent on the trading companies' steamers. Some of them were then leaving coconuts uncollected on 
the ground, and many were malarious and lonely, the family having shifted to Australia. But most of all it reveals how those who are poorly paid and on the lowest rank in a racially segregated society retain dignity, have fun, and keep alive something of their own history. It is also a good anecdote because it is not dependent on the final punch line, but has a sequence of accumulating incidents, all of them interesting, all illuminating and all funny.

But while I have chosen to use steamer day and the great hariap as an example of an anecdote, I have not exploited it in a published form. It is too long. It is hard to fit into history on radio or on the page. It dominates by its length and in its hilarious imagery. It means a long separation between the introductory setting and the conclusions that might be drawn from it.

Other great anecdotes from Papua New Guinea and from the prisoners of war bring with them the same merits and problems: they have become beautifully constructed, they offer numerous delights of image, incident and side-track, and they tell us much about the history of a particular community, but they are difficult to use in the history that historians publish. I think of a story that I have heard Slim DeGrey tell and which he included in his reminiscences of Changi, the story of the eight-man dog. The historian wants a concise and immediately relevant anecdote - like Alan Powell's use of the despondent Mark Pitt and the lack of discipline in the villagers of war-torn Cape Gloucester.

While steamer day at Axel's is still fresh, I want to draw attention to another characteristic of jokes. They come out of particular cultures and they draw their type of humour and style of telling from those cultures. Steamer day has many of the characteristics of jokes told in Papua New Guinea. Often Pidgin, Tok Pisin, is the language of jokes. Everybody knows the story, it has many incidents, often slapstick, often violent, there are many laughs along the way, the repetitions in Pidgin seem to work so well - 'isi isi', 'planti planti', 'longwe longwe moa iet' - and the accumulating incidents may end in chaos. That style is different from that influencing Strawb: he was expected to be concise, be clever in his use of language ('retaliate first'), have a fine control of the narrative, and be understated. All of you will know the New York Jewish loser style that Woody Allen uses - the stories in which he is going home from analysis and is beaten up by Quakers. Or the jokes of the late Dave Allen in which he talked of the triangular relationship between Irish parishioners, priest and God. If - as is obvious - the style of a joke is influenced by the culture of origin, then equally obviously jokes can be used to tell us much about those cultures. Historians who must always enter another culture, a culture separated from the researcher by time and usually by both time and place, ought to believe that they can make comprehensible the jokes of others. If they can not do that then neither can they say much about the religion or politics or social relations of other communities. 
I mentioned a third category of what we might broadly think of as a joke, and that is wit in words. We have had the example from Michael Young in which Malinowski provided the polish and his Scandinavian mate the finish. But historians have a great advantage in their writing because they can and should take those words and phrases that are so evocative of time and place, and also are compressed jokes. To take a simple example: the Hagen overcoat. In the highlands of New Guinea it sometimes gets cold, and on higher slopes there may be frosts. People do not wear clothes on the upper part of the body, so in the cold they can be seen with arms across their chests, hugging themselves. It is a common sight in the morning around Mt Hagen where there may be frost on the high slopes. So to have hunched shoulders and crossed arms to keep out the cold is to wear the Hagen overcoat.

The prisoners-of-war were inventive with language. To be 'Jap-happy' was to be too friendly or obsequious to the guards. But as the prisoners' uniforms wore out many found they had to adopt Japanese clothes, and often they worked or knocked around camp in the length of cloth that wound around the waist and between the legs. That also became known as a 'Jap-happy'. Men found that they could steal food when out on work details and smuggle it back to camp in a Jap-happy. That was called crutching. One of the most resourceful Jap-happy crutchers managed to carry a live chook back to camp. His record as the champion Jap-happy crutcher was challenged by Snow Peat - he crutched a pineapple, rough end and all. Now, not all communities have vocabularies with the sophistication and subtlety of that example, but all have words that are loaded with values, that are evocative of time and place and are often witty. They are there to be exploited - not too often, but often enough to help a reader enter that other time that we have researched.

When writing history, irony is an excellent tool. Gentle, subtle irony works best. If we use heavy sarcasm or lapse into the absurd, it is too hard to bring the reader back to serious revelations. We risk losing control of genre and purpose. But too often historians and other social scientists deploy irony against the easy targets. Many of us cannot avoid irony when we describe and quote a nineteenth-century missionary, a colonial official instructing villagers on hygiene, a planter sitting on his cane chair being served a drink by a black servant, a British army officer on the Northwest Frontier or in the Boer War. We send up the stereotype. That has all been done too often. But again I think that Michael Young gets it about right. He admires and is sympathetic to Malinowski, but after Malinowski has flattered a fourth or fifth attractive woman by seeming to want her judgment on complex issues, encouraged her to work with him, gone to bed with her, then quickly tried to untangle the relationship and written a profound and lengthy analysis of his own psychological state and morality, Young does employ restrained, effective irony. 
I have mentioned that jokes have a history, and I wanted to say something about collections of jokes that circle among particular groups of people and what they tell us about those people. Communities and cultures not only cultivate jokes of a certain style, they also have jokes with elements in common. The ones that I know most about are the racist jokes that were told by Australians in Papua New Guinea through much of the twentieth century, and the jokes that circulated among Australian servicemen. Both are rich historical sources, tell us much, and are under-used. Peter Stanley wrote a brief paper on Bluey and Curly cartoons. Bluey and Curly spent a lot of their black and white penned war in New Guinea. They were drawn by Alex Gurney and first appeared in the Melbourne Sun News Pictorial in February 1941. Amirah Inglis in her book Not a White Woman Safe: Sexual Anxiety and Politics in Port Moresby, 1920-1934, ANU Press, Canberra, 1974, used the story of the white woman and the towel story very well. And there are a few others who have drawn on jokes. But a rich field remains. Those who glean in that field have an obligation to both tell and analyse the jokes - both demand high skills.

There is one digger joke that I have always liked. It is from World War I, from the Great War. General William Birdwood, the Englishman, commanded the Anzac Corps, and by mid-1916 the Anzacs were in action on the Somme. You can imagine the trenches, churned mud, duckboards, and shell-holed no-man's land. Two diggers are leaning against the side of a trench, smoking and holding their .303 rifles casually in one hand. They watch a senior officer followed by an attendant junior officer pick his way along the trench. The diggers don't take their eyes off the two officers, but they don't shift to allow a wider passage and they don't salute. After the senior officer has passed the junior officer spins around and comes back. He says, 'Don't you who that was?' The diggers consider the question. One answers: 'Nope'. 'You ever met him, Barney?' 'Nah, not me'. 'That was General Birdwood'. And the first digger says, 'Well why doesn't he have feathers on his arse like any other bird would?'

This did not happen. It's imagined. But again it reveals much about the way some Australians want to see themselves. I reckon it's a great joke.

But my judgement of jokes has been known to be faulty. I once left a university meeting rather pleased with my profound and witty intervention. One of my more perceptive colleagues came up to me, and I was ready to receive his compliment on my wit. He said, 'Hank, there is a distinction that eludes you: that is the distinction between being smart and being a smart-arse'.

How many empiricists does it take to change a light globe?

We don't know. They just keep coming up with more anecdotal evidence. 
This text taken from The Boy from Boort: Remembering Hank Nelson, Edited by Bill Gammage, Brij V. Lal, Gavan Daws, published 2014 by ANU Press, The Australian National University, Canberra, Australia. 